\title{
COMPLEX ASSESSMENT OF THE ECOLOGICAL DEVELOPMENT OF THE COUNTRY'S REGIONS
}

\author{
Romualdas Ginevičius $^{1}$, Andrius Stasiukynas ${ }^{2}$, Dainora Gedvilaité ${ }^{3}$ \\ Department of Economics and Management of Enterprises, Business Management Faculty, \\ Vilnius Gediminas Technical University, Sauletekio al. 11, LT-10223 Vilnius, Lithuania \\ E-mails: 'romualdas.ginevicius@vgtu.lt; ${ }^{2}$ andrius.stasiukynas@vgtu.lt; \\ ${ }^{3}$ dainora.gedvilaite@vgtu.lt (corresponding author)
}

\begin{abstract}
Ecological development is one of the three components of sustainable development. To be able to analyse the impact of economic and social development on the ecological situation of the region, ecological development has to be assessed using quantitative methods. The ecological development of a region can be seen as a complex integrated phenomenon observed in many aspects. After formalizing them, i. e. converting them into criteria, we can form a system that upon applying multi-criteria methods will allow us to carry out a complex assessment of the ecological development of a region. The objective of this article is to provide methods for the quantitative assessment of the ecological state of a country's regions. Review of scientific literature, analysis of statistical data and the methods applied in the theory multiple criteria have been used for the research.
\end{abstract}

Keywords: sustainable development of regions, ecological development, multi-criteria methods, ecological development indicators, ecological development assessment, system of indicators.

JEL Classification: Q01; Q56.

\section{Introduction}

Today the development of any socioeconomic system is understood as sustainable development. The following concept of sustainable development has been formed in global environmental and economic development forums, which has become the classic concept: it is development that meets the current needs of society without compromising the ability of future generations to meet their own needs. Thus sustainable development is a compromise between the environmental, economic and social objectives of societies.

Sustainable development is especially relevant to regional politics, the aims of which are to reduce differences in the standard of life between different continents, countries, or regions of a country. The result of inefficient policies is the increase of social tension manifested by the extent of emigration, criminality, death rate, lower birth rate, etc.

One of the results of the unsustainable development of a country's regions is a deteriorating ecological situation due to the ineffective use of available resources, increased pollution, deforestation, etc.

Of the remaining two components of sustainable development - social and economic development - the latter has the biggest impact on ecology, as it covers industry, construction, transport, and agriculture. Studies of this issue carried out in different regions of the world clearly show the negative impact of economic development on the environment (Pope et al. 2004; Munitlak et al. 2009; Golusin, Munitlak 2009; Lapinskienè et al. 2014, 2015). To analyse the impact of economic development on ecological development, we need to express both of these components of sustainable development in a quantitative way.

Both the economic and ecological development of a region are attributed to complex integrated phenomena which manifest as many aspects in reality. Upon formalizing these aspects we obtain a system of indicators defining the analysed phenomenon. Where it consists of many indicators, a hierarchic system of indicators is formed (Ginevičius et al. 2014; Ginevičius 2009). This allows reducing the number of indicators assessed at one time by determining their weight by employing the expert method.

After carrying out a multi-criteria assessment of such a system of indicators, depending on the assessed objective, it is possible to determine the state of economic or ecological development of an individual region or to rank regions according to the degree of development. 
The objective of this article is to provide methods for the quantitative assessment of the ecological state of a country's regions and verify such methods against the regions of Lithuania.

\section{Assessment of the ecological development state of a country's regions}

Two essential aspects of the analysis of ecological development can be distinguished. First of all, the formation of a system of indicators that reflect it; second, the way or method of the quantitative assessment of the state of ecological development.

All authors analysing ecological development unanimously agree that it is a complex integrated phenomenon manifested by many aspects in reality. In order to carry out a quantitative assessment of ecological state, these aspects are formalized and converted into indicators.

Opinions concerning the composition of indicators differ. Today the situation is such that it is attempted to provide as many indicators reflecting ecological development as possible, but practical calculations use only a small number of such indicators (Atkisson, Hatcher 2001; Golusin et al. 2011; Boggia, Cortina 2010; Munitlak et al. 2009; Babu, Datta 2015; Wallis et al. 2011). This is due to several reasons. First, it is taken into account which indicators were used in previous studies; second, the availability of data about these indicators; third, the accuracy of such data (Golusin et al. 2011). In most cases it is based on indicators for which official data is available.

One more aspect of the analysis of ecological development has to be stressed - the object of most studies are either individual continents and the countries thereon or the countries of a continent, or the annual dynamics of the state of ecological development in individual countries (Wong 2002; Munitlak et al. 2009; Golusin, Munitlak 2009; Ferrarini et al. 2001). Very few studies concentrate on the ecological development of a country's regions (Wallis et al. 2011; Giddings et al. 2002).

Their number in the suggested systems of ecological development indicators is different and varies from several to several dozens. For example, the study of the Southeast region of Europe is based on a system of ten indicators (Golusin et al. 2011), another study is based on nine indicators (Boggia, Cortina 2010), systems of four (Kondyli 2010; Čiegis et al. 2010) and seven indicators (Babu, Datta 2015; Wallis et al. 2011), etc. are also suggested.

A more detailed analysis showed that indicators are often selected by way of decomposition.
This compounds the calculations and reduces accuracy. Especially since such indicators often reflect one and the same - a rather homogenous aspect, for example, certain pollutants expelled by certain sources. Therefore we believe that ecological development can be rather adequately reflected by a rather limited number of essential indicators. In such a case, the possibility to obtain information on those indicators increases.

Another important moment when forming a system of indicators is the possibility to obtain data about such indicators in the required cross-section. The object of our study is the ecological development of a country's region and its calculation on the basis of the regions of Lithuania, thus we based the study on information about their ecological development provided by Statistics Lithuania (2011, 2012, 2013). The following indicators were provided (Counties of Lithuania 2010, 2011, 2012):

- Collected and consumed water (thou. $\mathrm{m}^{3}$ );

- Released waste water (thou. $\mathrm{m}^{3}$ ).

- Pollutants expelled from stationary sources of pollution $(\mathrm{t})$.

- Area of forests compared to the area of the region (percentage).

In this case the system of indicators of the ecological development of the regions of Lithuania is shown in Figure 1.

As you can see, all indicators of ecological development are converted into relative indicators to assess adequately the ecological development of the country's regions.

The values of ecological development indicators of the regions of Lithuania for 2010-2012 are provided in Table 1.

Literature analysis on the quantitative assessment of the state of ecological development showed that mostly multi-criteria methods are employed (Boggia, Cortina 2010; Krajnc, Glavic 2005; Kevin 2007; Ferrarini et al. 2001; Zhou et al. 2007). In such a case it is attempted to consolidate ecological development indicators expressed in different dimensions with a different impact on this development into one aggregate value.

Two models of such aggregation are distinguished. The first can be shown in this way (Golusin et al. 2011):

$$
E j=\sum_{i=1}^{l} w_{i}^{+} \widetilde{q}_{i}^{+}-\sum_{i=1}^{n} w_{i}^{-} \widetilde{q}_{i}^{-},
$$

where $E_{j}$ - the value of the quantitative assessment of the state of ecological development of an analysed phenomenon j (region, country, country's 
region, etc.); $w_{i}^{+}-$the weight of factor i improving the ecological situation; $w_{i}^{-}$- the weight of factor $\mathrm{i}$ aggravating the ecological situation; $\widetilde{q}_{i}^{+}-$the normalized value of factor i improving the ecological situation; $\widetilde{q}_{i}^{-}-$the normalized value of factor $i$ aggravating the ecological situation.

Thus in this case (1) the nature of the change of factors in the formula is not changed, i.e. it includes both maximizing and minimizing factors.

The quantitative assessment of the state of ecological development may also be done by applying a multi-criteria model based on the SAW
(Simple Additive Weighting) method (Hwang, Yoon 1981):

$$
E_{j}^{S A W}=\sum_{i=1}^{n} w_{i} \widetilde{q}_{i}
$$

where: $E_{j}^{S A W}$ - the value of the quantitative assessment applying the SAW method of the state of ecological development of an analysed phenomenon $\mathrm{j}$ (region, country, country's region, etc.); $w_{i}$ the weight of indicator $\mathrm{i} ; \widetilde{q}_{i}$ - the normalized value of indicator $i$.

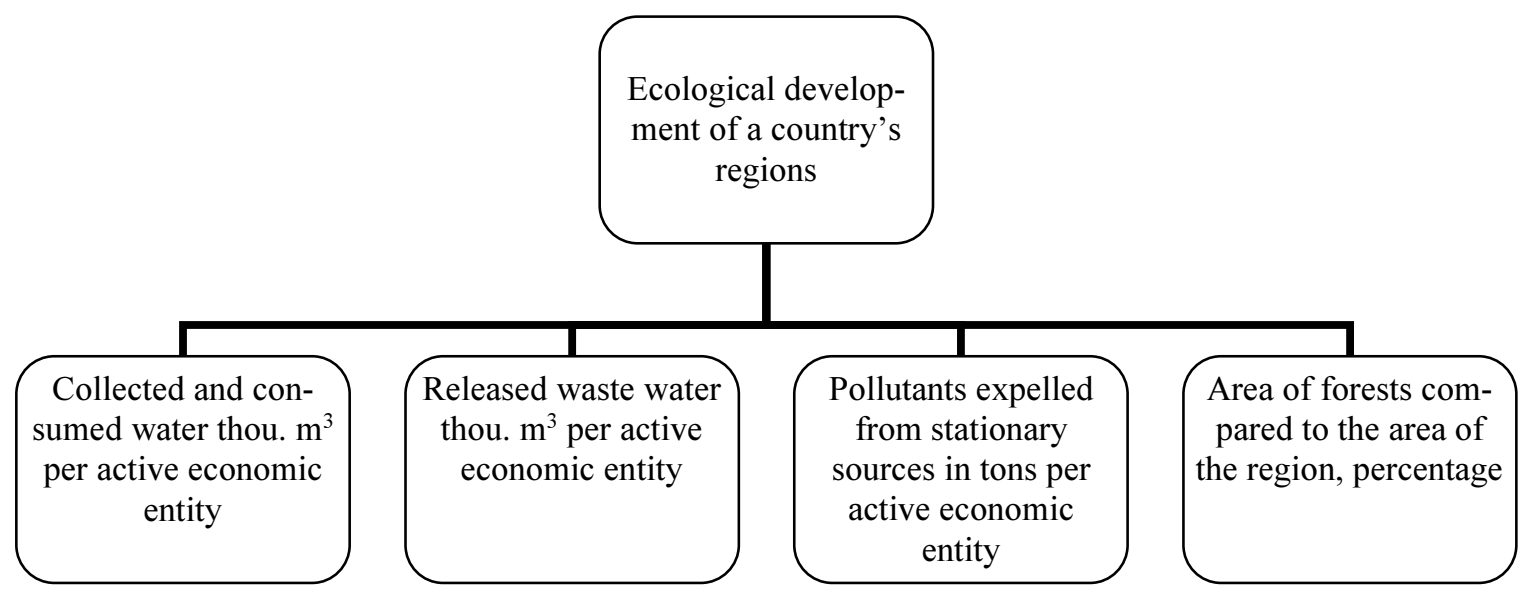

Fig. 1. System of indicators of the ecological development of the regions of Lithuania

(Source: compiled by the authors)

Table 1. Values of ecological development indicators of the regions of Lithuania for 2010-2012 (Source: Statistics Lithuania 2011, 2012, 2013)

\begin{tabular}{|c|c|c|c|c|c|c|c|c|c|c|c|c|}
\hline \multirow{3}{*}{$\begin{array}{l}\text { Name of } \\
\text { the region }\end{array}$} & \multicolumn{12}{|c|}{ Name of ecological development indicators } \\
\hline & \multicolumn{3}{|c|}{$\begin{array}{l}\text { Collected and consumed } \\
\text { water (thou. } \mathrm{m}^{3} \text { ) }\end{array}$} & \multicolumn{3}{|c|}{$\begin{array}{l}\text { Released waste water } \\
\quad\left(\text { thou. } \mathrm{m}^{3}\right)\end{array}$} & \multicolumn{3}{|c|}{$\begin{array}{l}\text { Pollutants expelled from } \\
\text { stationary sources of } \\
\text { pollution (tons) }\end{array}$} & \multicolumn{3}{|c|}{$\begin{array}{l}\text { Area of forests compared } \\
\text { to the area of the region } \\
\text { (percentage) }\end{array}$} \\
\hline & 2010 & 2011 & 2012 & 2010 & 2011 & 2012 & 2010 & 2011 & 2012 & 2010 & 2011 & 2012 \\
\hline Vilnius & 910574.2 & 653699.8 & 806213 & 461662.2 & 332406.2 & 410880.1 & 7289.8 & 7117.4 & 6818.8 & 0.43695 & 0.44003 & 0.43900 \\
\hline Kaunas & 6412204 & 4956064 & 4699623 & 3202221 & 2472541 & 2337299 & 10477.4 & 11118.1 & 10909.7 & 0.29595 & 0.29595 & 0.29694 \\
\hline laipèda & 48132 & 45357.9 & 48284 & 34164 & 34488.2 & 34760.7 & 5786.4 & 4842.9 & 4902.6 & 0.26396 & 0.26396 & 0.26396 \\
\hline lytus & 20382.3 & 20812.8 & 11.7 & 10267.5 & 9863.6 & 89 & 132 & 128 & 143 & 0.49106 & 0.49106 & 0.48995 \\
\hline $\begin{array}{l}\text { arijam- } \\
\text { lè }\end{array}$ & 19467.1 & 19932.7 & 2513.2 & 12340.8 & 12390.1 & 13403 & 1929.7 & 2238.5 & 2057.1 & 0.21689 & 0.21689 & 0.2168 \\
\hline Panevėžys & 3994.2 & 23626.2 & 23774.3 & 16395 & 15305.4 & 16755.4 & 2788.7 & 2936.1 & 3360.7 & 028194 & 0.28194 & 0.2819 \\
\hline auliai & 23240 & 23254 & 23167 & 18415 & 18677 & 2938538 & 5199.5 & 7395.3 & 7227.1 & 0.32400 & 0.32400 & 0.3240 \\
\hline Telšiai & 19059 & 19369.5 & 20237 & 11990 & 14109 & 14022 & 26420 & 28080.5 & 25411.3 & 0.36092 & 0.36092 & 0.3609 \\
\hline Utena & 209150.8 & 2055244 & 158060 & 103692.2 & 103524 & 80071.6 & 1951.4 & 1667.1 & 1861.2 & 0.34106 & 0.34106 & 0.3410 \\
\hline auragè & 5752 & 5422.4 & 5379 & 3488 & 4119 & 3988 & 712.5 & 833.3 & 877.5 & 0.33008 & 033008 & 0.3300 \\
\hline
\end{tabular}


The SAW method (Hwang, Yoon 1981) is used in the reaearch.

Table 1 distinguishes two circumstances which need to be evaluated, first, the nature of ecological development indicators is different: the first three are minimizing, while the fourth is maximizing. This means that the growing values of the first three indicators signal a deterioration of the ecological situation, and the increase of the value of the fourth indicator signals an improvement of the situation. The multi-criteria assessment SAW method requires the nature of change of all indicators to be the same, i.e. all of them need to be maximizing or minimizing.

Maximization of the values of indicators is performed in the following way (Hwang, Yoon 1981):

$$
q_{i}^{\max }=\frac{q_{i \min }}{q_{i}},
$$

where: $q_{i}^{\max }-$ the maximized value of indicator $\mathrm{i}$; $q_{i}$ - the value of indicator $\mathrm{i} ; q_{i \min }-$ the lowest value of indicator i for all regions.

Minimization of values of indicators is done in the following way (Hwang, Yoon 1981):

$$
q_{i}^{\min }=\frac{q_{i}}{q_{i \max }},
$$

where: $q_{i}^{\min }-$ the minimized value of indicator $\mathrm{i}$; $q_{i \max }$ - the highest possible value of indicator i for all regions.

Similarly to the perspective in the first case, the second aspect is that ecological development indicators are expressed in different dimensions, i.e. they are incomparable. The values need to be normalized to become comparable. The method of normalization depends on the objective of multicriteria assessment. If we want to rank the regions of the country according to the degree of ecological development, normalization is performed in the following way (Ginevičius, Podvezko 2004, 2007; Ginevičius et al. 2006):

$$
\widetilde{q}_{i}=\frac{q_{i}}{\sum_{i=1}^{n} q_{i}},
$$

where: $\widetilde{q}_{i}-$ the normalized value of indicator $\mathrm{i}$ ( $i=1, \bar{n}, \mathrm{n}$ - number of indicators).

In the event that we want to use the results of integrated ecological development assessment of regions for further research, for example the analy- sis of the impact of economic development, then this method of the normalization of values of indicators is not suitable. This is due to the fact that seeking the comparability of regions the normalized value of indicator i taken individually results from the general context, i.e. this value is influenced by the values of this indicator of all other regions.

We need to determine the state of ecological development of an individual region of a country, therefore we should perform normalization employing the ESP method (Ginevičius et al. 2012, 2015; Ginevičius 2008):

$$
\widetilde{q}_{i}=\frac{q_{i}}{q_{i \max }},
$$

where: $\widetilde{\widetilde{q}}_{i}-$ the normalized value of indicator $\mathrm{i}$; $q_{i \max }-$ the highest value of indicator i (obtained from statistical data or established through expert assessment).

In this case the value of indicator $\widetilde{\widetilde{q}}_{i}$ for the analysed region does not depend on the values of the same indicators of other regions.

Based on Table 1 and formula (4) the maximization of the values of ecological development of regions was performed. The results are presented in Table 2.

The next phase of multi-criteria assessment is the normalization of indicator values, i.e. their conversion into non-dimensional comparable values. Based on Table 2 and formula (5) the following results were obtained (Table 3 ).

The weights of ecological development indicators of the regions were determined by interviewing experts. After the verification of the compatibility of their opinions using the Pearson criteria $\chi^{2}$, the following values were obtained (Table 4).

After obtaining normalized indicator values and weights of the indicators, we can continue to the quantitative integrated assessment of the ecological development of the regions of Lithuania. This is performed using the SAW method (Hwang, Yoon 1981). In one case we ranked the regions according to ecological development (Table 5), and in the other case we determined the state of ecological development of every region (Table 6).

The ranking of the regions of the country according to ecological development (Table 5) can be used as a basis for formulating the measures of regional development intended to reduce differences between regions. This can be done by respectively directing the domestic investment of the country. 
Table 2. Maximized values of ecological development indicators of the regions of Lithuania (Source: compiled by the authors)

\begin{tabular}{|c|c|c|c|c|c|c|c|c|c|c|c|c|}
\hline \multirow{3}{*}{$\begin{array}{l}\text { Name of } \\
\text { the region }\end{array}$} & \multicolumn{12}{|c|}{ Name of ecological development indicators } \\
\hline & \multicolumn{3}{|c|}{$\begin{array}{c}\text { Collected and consumed water } \\
\text { (thou. } \mathrm{m}^{3} \text { ) per active economic } \\
\text { entity }\end{array}$} & \multicolumn{3}{|c|}{$\begin{array}{l}\text { Released waste water (thou. } \mathrm{m}^{3} \text { ) } \\
\text { per active economic entity }\end{array}$} & \multicolumn{3}{|c|}{$\begin{array}{c}\text { Pollutants expelled from } \\
\text { stationary sources of pollution } \\
\text { (tons) per active economic entity }\end{array}$} & \multicolumn{3}{|c|}{$\begin{array}{l}\text { Area of forests compared to } \\
\text { the area of the region } \\
\text { (percentage) }\end{array}$} \\
\hline & 2010 & 2011 & 2012 & 2010 & 2011 & 2012 & 2010 & 2011 & 2012 & 2010 & 2011 & 2012 \\
\hline Vilnius & 0.09395 & 0.12323 & 0.10230 & 0.11238 & 0.18409 & 0.14883 & 1 & 1 & 1 & 0.43695 & 0.44003 & 0.43900 \\
\hline Kaunas & 0.00765 & 0.00929 & 0.00999 & 0.0093 & 0.01415 & 0.01490 & 0.39938 & 0.36602 & 0.35604 & 0.29595 & 0.29595 & 0.29694 \\
\hline Klaipèda & 0.62105 & 0.607797 & 0.570431 & 0.530608 & 0.60721 & 0.58745 & 0.440187 & 0.50293 & 0.46443 & 0.26396 & 0.26396 & 0.26396 \\
\hline Alytus & 0.44769 & 0.421312 & 0.443854 & 0.538926 & 0.67530 & 0.721865 & 0.587718 & 0.60144 & 0.50294 & 0.49106 & 0.49106 & 0.48995 \\
\hline $\begin{array}{l}\text { Marijam- } \\
\text { polé }\end{array}$ & 0.44388 & 0.395295 & 0.352173 & 0.424604 & 0.48307 & 0.438576 & 0.38154 & 0.31098 & 0.31862 & 0.21689 & 0.21689 & 0.21689 \\
\hline Panevėžys & 0.72318 & 0.677925 & 0.660289 & 0.641802 & 0.79493 & 0.694609 & 0.530167 & 0.48196 & 0.38615 & 0.28194 & 0.28194 & 0.28194 \\
\hline Šiauliai & 0.83609 & 0.785571 & 0.799612 & 0.639849 & 0.74297 & 0.004674 & 0.318413 & 0.21824 & 0.2119 & 0.32400 & 0.32400 & 0.32400 \\
\hline Telšiai & 0.49866 & 0.447319 & 0.434231 & 0.480671 & 0.46648 & 0.464633 & 0.03065 & 0.02726 & 0.02858 & 0.36092 & 0.36092 & 0.36092 \\
\hline Utena & 0.03918 & 0.037322 & 0.046932 & 0.047925 & 0.05628 & 0.068686 & 0.357822 & 0.40651 & 0.32949 & 0.34106 & 0.34106 & 0.34106 \\
\hline Tauragė & 1 & 1 & 1 & 1 & 1 & 1 & 0.687851 & 0.57490 & 0.50675 & 0.33008 & 0.33008 & 0.33008 \\
\hline
\end{tabular}

Table 3. Normalized values of ecological development indicators of the regions of the country for 2010-2012 (Source: compiled by the authors)

\begin{tabular}{|c|c|c|c|c|c|c|c|c|c|c|c|c|}
\hline \multirow{3}{*}{$\begin{array}{l}\text { Name of } \\
\text { the region }\end{array}$} & \multicolumn{12}{|c|}{ Name of ecological development indicators } \\
\hline & \multicolumn{3}{|c|}{$\begin{array}{l}\text { Collected and consumed water } \\
\text { (thou. } \mathrm{m}^{3} \text { ) per active } \\
\text { economic entity }\end{array}$} & \multicolumn{3}{|c|}{$\begin{array}{c}\text { Released waste water } \\
\text { (thou. } \mathrm{m}^{3} \text { ) per active economic } \\
\text { entity }\end{array}$} & \multicolumn{3}{|c|}{$\begin{array}{c}\text { Pollutants expelled from } \\
\text { stationary sources of pollution } \\
\text { (tons) per active economic entity }\end{array}$} & \multicolumn{3}{|c|}{$\begin{array}{l}\text { Area of forests compared to the } \\
\text { area of the region (percentage) }\end{array}$} \\
\hline & 2010 & 2011 & 2012 & 2010 & 2011 & 2012 & 2010 & 2011 & 2012 & 2010 & 2011 & 2012 \\
\hline Vilnius & 0.09395 & 0.12323 & 0.10230 & 0.11238 & 0.18409 & 0.14883 & 1 & 1 & 1 & 0.88981 & 0.89609 & 0.89602 \\
\hline Kaunas & 0.00765 & 0.00929 & 0.00999 & 0.0093 & 0.01415 & 0.01490 & 0.39938 & 0.36602 & 0.35604 & 0.60269 & 0.60269 & 0.60607 \\
\hline Klaipeda & 0.62108 & 0.60779 & 0.57043 & 0.53060 & 0.60721 & 0.58745 & 0.44018 & 0.50293 & 0.46443 & 0.53754 & 0.53754 & 0.53875 \\
\hline Alytus & 0.44769 & 0.42131 & 0.44385 & 0.53892 & 0.67530 & 0.72186 & 0.58771 & 0.60144 & 0.50294 & 1 & 1 & 1 \\
\hline $\begin{array}{l}\text { Marijam- } \\
\text { polè }\end{array}$ & 0.44388 & 0.39529 & 0.35217 & 0.42460 & 0.48307 & 0.43857 & 0.38154 & 0.31098 & 0.31862 & 0.44168 & 0.44168 & 0.44268 \\
\hline Panevėžys & 0.72318 & 0.67792 & 0.66028 & 0.64180 & 0.79493 & 0.69460 & 0.53016 & 0.48196 & 0.38615 & 0.57415 & 0.57415 & 0.57545 \\
\hline Šiauliai & 0.83609 & 0.78557 & 0.79961 & 0.63984 & 0.74297 & 0.00467 & 0.31841 & 0.21824 & 0.2119 & 0.65980 & 0.65980 & 0.66129 \\
\hline Telšiai & 0.49866 & 0.44731 & 0.43423 & 0.48067 & 0.46648 & 0.46463 & 0.03065 & 0.02726 & 0.02858 & 0.73498 & 0.73498 & 0.73664 \\
\hline Utena & 0.03918 & 0.03732 & 0.04693 & 0.04792 & 0.05628 & 0.06868 & 0.35782 & 0.40651 & 0.32949 & 0.69454 & 0.69454 & 0.69611 \\
\hline Tauragè & 1 & 1 & 1 & 1 & 1 & 1 & 0.68785 & 0.574909 & 0.506757 & 0.672187 & 0.72187 & 0.673704 \\
\hline
\end{tabular}

Table 4. Weights of ecological development indicators of the regions of Lithuania (Source: compiled by the authors)

\begin{tabular}{c|c|c|c|c|c}
\hline $\begin{array}{c}\text { Name of the } \\
\text { indicator }\end{array}$ & $\begin{array}{c}\text { Collected and con- } \\
\text { sumed water (thou. } \\
\mathrm{m}^{3} \text { ) per active eco- } \\
\text { nomic entity }\end{array}$ & $\begin{array}{c}\text { Released } \\
\text { waste water } \\
\text { (thou. } \mathrm{m}^{3} \text { ) per } \\
\text { active eco- } \\
\text { nomic entity }\end{array}$ & $\begin{array}{c}\text { Pollutants expelled from } \\
\text { stationary sources of pollu- } \\
\text { tion (tons) per active eco- } \\
\text { nomic entity }\end{array}$ & $\begin{array}{c}\text { Area of forests } \\
\text { compared to the } \\
\text { area of the region } \\
\text { (percentage) }\end{array}$ & $\begin{array}{c}\text { Total } \\
\text { Weight of the indi- } \\
\text { cator }\end{array}$ \\
\hline
\end{tabular}


Table 5. Regions of Lithuania ranked according to their ecological development (Source: compiled by the authors)

\begin{tabular}{c|l|l|c|c|c|c|c}
\hline \multirow{2}{*}{ No. } & \multirow{2}{*}{ Regions } & \multicolumn{2}{|c|}{2010} & \multicolumn{2}{c|}{2011} & \multicolumn{3}{c}{2012} \\
\cline { 3 - 8 } & & Value & Rank & Value & Rank & Value & Rank \\
\hline 1. & Vilnius & 0.12749 & 2 & 0.136838 & 2 & 0.146103 & 2 \\
\hline 2. & Kaunas & 0.05176 & 9 & 0.050541 & 10 & 0.053351 & 10 \\
\hline 3. & Klaipėda & 0.10533 & 6 & 0.115748 & 5 & 0.11799 & 4 \\
\hline 4. & Alytus & 0.118788 & 4 & 0.125188 & 3 & 0.127143 & 3 \\
\hline 5. & Marijampole & 0.084732 & 7 & 0.077469 & 7 & 0.081089 & 6 \\
\hline 6. & Panevéžys & 0.124558 & 3 & 0.123446 & 4 & 0.117954 & 5 \\
\hline 7. & Siauliai & 0.109375 & 5 & 0.099759 & 6 & 0.080895 & 7 \\
\hline 8. & Telšiai & 0.056785 & 8 & 0.052572 & 9 & 0.055652 & 8 \\
\hline 9. & Utena & 0.051701 & 10 & 0.059211 & 8 & 0.055471 & 9 \\
\hline 10. & Tauragė & 0.169481 & 1 & 0.159229 & 1 & 0.164352 & 1 \\
\hline
\end{tabular}

Table 6. Results of multi-criteria assessment of ecological development of the regions of Lithuania (Source: compiled by the authors)

\begin{tabular}{c|l|l|c|c|c|c|c}
\hline \multirow{2}{*}{ No. } & \multirow{2}{*}{ Regions } & \multicolumn{2}{|c|}{2010} & \multicolumn{2}{c}{2011} & \multicolumn{2}{c}{2012} \\
\cline { 3 - 8 } & & Value & Rank & Value & Rank & Value & Rank \\
\hline 1. & Vilnius & 0.629329 & 2 & 0.648033 & 2 & 0.637504 & 2 \\
\hline 2. & Kaunas & 0.263273 & 10 & 0.247726 & 10 & 0.243366 & 10 \\
\hline 3. & Klaipėda & 0.50871 & 6 & 0.548255 & 5 & 0.516819 & 5 \\
\hline 4. & Alytus & 0.586622 & 4 & 0.607345 & 3 & 0.570716 & 3 \\
\hline 5. & Marijampolè & 0.4096 & 7 & 0.370946 & 7 & 0.357412 & 7 \\
\hline 6. & Panevėžys & 0.599565 & 3 & 0.587119 & 4 & 0.519884 & 4 \\
\hline 7. & Šiauliai & 0.530188 & 5 & 0.482941 & 6 & 0.372684 & 6 \\
\hline 8. & Telšiai & 0.28559 & 8 & 0.268932 & 9 & 0.266211 & 8 \\
\hline 9. & Utena & 0.26535 & 9 & 0.290487 & 8 & 0.256393 & 9 \\
\hline 10. & Taurage & 0.811144 & 1 & 0.754673 & 1 & 0.720749 & 1 \\
\hline
\end{tabular}

Data about the ecological development of an individual region (Table 6) can be used, for instance, for the correlation-regression analysis of the impact of economic development on ecology.

\section{Conclusions}

In order to carry out the quantitative assessment of the state of the ecological development of a region of the country, first we need to solve two problems. First of all to form a system of indicators; secondly, to determine the method of aggregating such indicators into one cumulative value.

Different systems of indicators have been suggested. They differ both in the number of indicators and their composition. In many instances their structure is determined by three circumstances: first, the indicators used in previous studies; second, the availability of data about such indicators; third, the accuracy of the data. On the other hand, systems of indicators are often too detailed, which encumbers calculations and reduces accuracy, therefore the system should only include essential indicators that contain related indicators of a lower level.

There are two methods of aggregating ecological development indicators expressed by different dimensions and operating in different directions into one cumulative value. First, where the nature of the change of factors is not changed, i.e. they remain maximizing or minimizing. Second, where through transformation all the factors become maximizing or minimizing and only then are aggregated into one cumulative value. Further research will show which of the methods is more accurate. 


\section{References}

Atkisson, A.; Hatcher, R. 2001. The compass index of sustainability: prototype for a comprehensive sustainability information system, Journal of Environmental Assessment Policy and Management 3(4): 509-532.

Babu, S.; Datta, S. K. 2015. Revisiting the link between socio-economic development and environmental status indicators - focus on panel data, Environment, Development and Sustainability 17(3): 567586. http://dx.doi.org/10.1007/s10668-014-9561-6

Boggia, A.; Cortina, C. 2010. Measuring sustainable development using a multi-criteria model: a case study, Journal of Environmental Management 91: 2301-2306. http://dx.doi.org/10.1016/j.jenvman.2010.06.009

Čiegis, R.; Ramanauskienè, J.; Šimanskienè, L. 2010. Lietuvos regionu darnaus vystymosi vertinimas [Evaluation of sustainable development of Lithuanian regions]. Klaipeda: Klaipèdos universiteto leidykla (in Lithuanian).

Ferrarini, A.; Bodini, A.; Becchi, M. 2001. Environmental quality and sustainability in the province of Reggio Emilia (Italy): using multi-criteria analysis to assess and compare municipal performance, Journal of Environmental Management 63: 117131. http://dx.doi.org/10.1006/jema.2001.0465

Giddings, B.; Hopwood, B.; O’Brien, G. 2002. Environment, economy and society: fitting them together into sustainable development, Sustainable Development 10: 187-196. http://dx.doi.org/10.1002/sd.199

Ginevičius, R. 2008. Normalization of quantities of various dimensions, Journal of Business Economics and Management 9(1): 79-86. http://dx.doi.org/10.3846/1611-1699.2008.9.79-86

Ginevičius, R. 2009. Socioekonominių sistemų būklès kiekybinio ivertinimo problematika [Some problems of quantitative evaluation of the state of social-economic systems], Verslas: teorija ir praktika 10(2): 69-83 (in Lithuanian). http://dx.doi.org/10.3846/1648-0627.2009.10.69-83

Ginevičius, R.; Butkevičius, A.; Podvezko, V. 2006. Complex evaluation of economic development of the Baltic States and Poland, Ekonomický Časopis 9(54): 918-930.

Ginevičius, R.; Gedvilaitè, D.; Bruzgè, Š. 2015. Assessment of a country's regional economic development on the basis of Estimation of a Single Process (ESP) method, Entrepreneurial Business and Economics Review (EBER) 3(2): 141-153. http://dx.doi.org/10.15678/EBER.2015.030210

Ginevičius, R.; Hogeforster, M.; Gedvilaitè, D. 2014. The formation of the system of indicators of development of the country's regions, in $8^{\text {th }}$ International Scientific Conference "Business and Management 2014”, 15-16 May 2014, Vilnius, Lithuania.
Ginevičius, R.; Podvezko, V. 2004. Complex evaluation of the use of information technologies in the countries of Easters and Central Europe, Journal of Business Economics and Management 5(4): 183191.

Ginevičius, R.; Podvezko, V. 2007. Complex assessment of sustainable development of state regions with emphasis on ecological and dwelling conditions, Ekologija 53: 41-48.

Ginevičius, R.; Podvezko, V.; Podvezko, A. 2012. A new approach for evaluating of socio-economical processes by muti-criteria decision methods, in $7^{\text {th }}$ International Scientific Conference "Business and Management 2012”, 10-11 May 2012, Vilnius, Lithuania.

Golusin, M.; Munitlak, O. I. 2009. Definition, characteristics and state of the indicators of sustainable development in countries of Southeastern Europe, Agriculture, Ecosystems and Environment 130: 67-74. http://dx.doi.org/10.1016/j.agee.2008.11.018

Golusin, M.; Munitlak, O. I.; Teodorovic, N. 2011. The review of the achieved degree of sustainable development in South Eastern Europe - the use of linear regression method, Renewable and Sustainable Energy Reviews 15: 766-772.

http://dx.doi.org/10.1016/j.rser.2010.07.064

Hwang, C. L.; Yoon, K. 1981. Multiple attribute decision making-methods and applications. A state of the art survey. Berlin, Heidelberg, New York: Springer Verlag.

Kevin, F. R. L. 2007. Evaluating environmental sustainability: an integration of multiple-criteria decisionmaking and fuzzy logic, Environmental Management 39: 721-736. http://dx.doi.org/10.1007/s00267-005-0395-8

Kondyli, J. 2010. Measurement and evaluation of sustainable development - a composite indicator for the islands of the North Aegean region, Greece, Environmental Impact Assessment Review 30: 347-356. http://dx.doi.org/10.1016/j.eiar.2009.08.006

Krajnc, D.; Glavic, P. 2005. A model for integrated assessment of sustainable development, Resources, Conservation and Recycling 43: 189-208. http://dx.doi.org/10.1016/S0921-3449(04)00120-X

Lapinskienè, G.; Tvaronavičienè, M.; Vaitkus, P. 2014. The emissions of greenhouse gases and economic growth - the evidence of the presence of the environmental Kuznets curve in the European Union countries, Technological and Economic Development of Economy 20(1): 65-78. http://dx.doi.org/10.3846/20294913.2014.881434

Lapinskiene, G.; Peleckis, K.; Radavičius, M. 2015. Economic development and greenhouse gas emissions in the EU countries, Journal of Business Economics and Management 16(6): 1131-1145. http://dx.doi.org/10.3846/16111699.2015.1112830 
Munitlak, O. I.; Golusin, M.; Dodic, S.; Dodic, J. 2009. Perspectives of sustainable development in countries of Southeastern Europe, Renewable and Sustainable Energy Reviews 13(8): 2179-2187. http://dx.doi.org/10.1016/j.rser.2009.03.004

Pope, G.; Annandale, D.; Morrison-Saunders, A. 2004. Conceptualising sustainability assessment, Environmental Impact Assessment Review 24(6): 595616. http://dx.doi.org/10.1016/j.eiar.2004.03.001

Statistics Lithuania. 2011. Counties of Lithuania 2010 [online]. Vilnius [cited 10 February 2016]. Available from Internet: http://osp.stat.gov.lt/servicesportlet/pub-edition-file?id=14761

Statistics Lithuania. 2012. Counties of Lithuania 2011 [online]. Vilnius [cited 10 February 2016]. Available from Internet: http://osp.stat.gov.lt/servicesportlet/pub-edition-file? $\mathrm{id}=2068$
Statistics Lithuania. 2013. Counties of Lithuania 2012 [online]. 2013. Vilnius [cited 10 February 2016]. Available from Internet: http://osp.stat.gov.lt/ services-portlet/pub-edition-file?id $=15047$

Wallis, A. M.; Graymore, L. M.; Richards, A. J. 2011. Significance of environment in the assessment of sustainable development: the case for south west Victoria, Ecological Economics 70(4): 595-605. http://dx.doi.org/10.1016/j.ecolecon.2010.11.010

Wong, C. 2002. Developing indicators to inform local economic development in England, Urban Studies 39(10): 1833-1863. http://dx.doi.org/10.1080/0042098022000002984

Zhou, J.; Xiao, H.; Shang, J; Zhang, X. 2007. Assessment of sustainable development system in Suihua City, China, Chinese Geographical Science 17(4): 304-310.

http://dx.doi.org/10.1007/s1 1769-007-0304-6 